\title{
BUCKLING OF THE STIFFENED FLANGE OF THE THIN-WALLED MEMBER AT LONGITUDINAL STRESS VARIATION
}

\section{A. SZYCHOWSKI ${ }^{1}$}

\begin{abstract}
Buckling of the stiffened flange of a thin-walled member is reduced to the buckling analysis of the cantilever plate, elastically restrained against rotation, with the free edge stiffener, which is susceptible to deflection. Longitudinal stress variation is taken into account using a linear function and a $2^{\text {nd }}$ degree parabola. Deflection functions for the plate and the stiffener, adopted in the study, made it possible to model boundary conditions and different buckling modes at the occurrence of longitudinal stress variation. Graphs of buckling coefficients are determined for different load distributions as a function of the elastic restraint coefficient and geometric details of the stiffener. Exemplary buckling modes are presented.
\end{abstract}

Keywords: thin-walled members, local buckling, distortional buckling, elastic restraint of the edge, longitudinal stress variation

\section{INTRODUCTION}

Presently used thin-walled members with open sections are characterised by high slenderness of the component walls (flanges, webs, etc.) Consequently, they are sensitive to local phenomena related to the stability loss of compressed walls. For that reason, the free edge of the cantilever compressed flange is often strengthened with the edge stiffener, resulting in an increase in the buckling critical stress [1].

${ }^{1}$ Kielce University of Technology, Faculty of Civil Engineering and Architecture, Al. 1000-lecia Państwa Polskiego 7 , 25-314 Kielce, Poland, e-mail: aszychow@tu.kielce.pl. 
Member is in uniform compression and a longitudinal stress variation occurs along the bar segment. Thin-walled bar segment is defined as a distance between transverse stiffeners (ribs, diaphragms), or Additionally, the section stability loss is also changed from local to distortional buckling mode, or the interaction of both [2].

In many load cases that are important from the technical standpoint, the stiffened flange of the supports that ensure the stiff section contour. A single or a double edge lip, or a welded stiffening element (e.g., a flat bar having the same or greater wall thickness) can act as a stiffener. In practice, such a flange can be analysed as a cantilever plate, elastically restrained against rotation, with the other edge stiffener which is susceptible to deflection $[3,4]$.

The problem of distortional buckling of the compressed cantilever plate with the free edge stiffener, at the constant stress intensity along the length, was solved in study [1]. In this case, it was assumed that the edge stiffener is symmetrical with respect to the plate middle line. For such a system, constructed of the plate and the "beam stiffener", an exact solution was obtained, as a result of integration of the stability equations. Study [1] also presented the graphs of buckling coefficients $(k)$ and approximation formulas obtained with the use of the energy method. In study [4], the scope of investigations presented in [1] was extended to include the case of the cantilever plate, elastically restrained against rotation around the supported edge, for the same thickness of the plate and the stiffener $\left(t_{s}=t_{L}\right)$. Furthermore, as in study [1], the effect of the torsional stiffness of the stiffener was disregarded.

Study [3] presented the results of investigations into the stability of cantilever plates with longitudinal free (unstiffened) edge at longitudinal stress variation and limit conditions (pin support and full fixity) on the other edge. The transverse edges were assumed to be simply supported. The formulas were derived for the work done by external forces at the load producing longitudinal stress distribution according to a linear function and a $2^{\text {nd }}$ degree parabola.

The stiffened cantilever wall is, in most cases, elastically restrained against rotation by the other internal wall (e.g., in the member web). In this case, the critical stress of local and distortional buckling depends upon the slenderness of the cantilever wall, longitudinal stress variation, elastic restraint coefficient and the stiffener geometry.

In studies $[5,6]$, the problem of the distortional buckling of the cold-formed member was solved by adopting the flexural-torsional stability loss model of the substitute thin-walled bar in the rotationalelastic medium. The rotational spring stiffness $\left(k_{\phi}\right)$, which accounts for the plate bending stiffness 
the of the web wall, was determined. The disadvantageous effect of compressive stress was accounted for in an approximate way. In that case, the substitute bar section consisted of the plate (compressed flange) and the edge stiffener (lip). In study [7], an interactive model of the buckling of the stiffened flange and web was adopted, which accounted for the geometric stiffness of those elements. The model employed in study [8] was similar to that in $[5,6]$. The difference was that the substitute rotational spring stiffness $k_{\phi^{*}<k \phi}$ was determined on the basis of the translational stiffness $k_{y}$ located at the centre of gravity of the plate - stiffener system. In this way, the effect of the bending stiffness of the flange itself was additionally taken into consideration. In the studies quoted above, constant stress distribution along the length of the thin-walled element was assumed. The buckling model chosen in the code [9] was that of flexural, axially compressed "substitute bar", which consisted of appropriate effective widths of the flange and the stiffener, after taking into account the possible local buckling of those. In this computational model, the "substitute bar" sits on the translational-elastic foundation having the module $K$, and is uniformly compressed along the length.
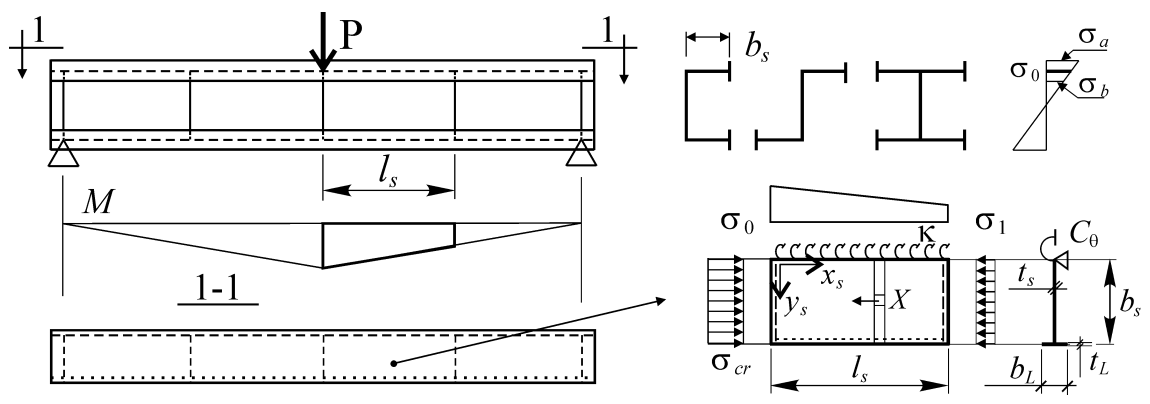

Figure 1. Compressed flange isolated from thin-walled bar segment

In study [10], the problem of the local buckling of axially compressed, non-symmetrically elastically restrained $\left(C_{\theta 1} \neq C_{\theta 2}\right)$ internal plate at longitudinal stress variation was solved.

To be able to solve many problems related to thin-walled member buckling under complex load cases, it is necessary to have solutions for distortional stability loss of the cantilever plate with the free edge stiffener, when the longitudinal stress variation is accounted for. Such solutions, however, are not available.

In the present study, the stability loss of the flange of the thin-walled member with open section is reduced to the buckling analysis of the cantilever plate with the other edge stiffened and susceptible 
to deflection. The plate is elastically restrained against rotation and longitudinal stress variation is taken into consideration. The computational model containing the cantilever plate and the "beam stiffener", the same as in studies $[1,4]$, is adopted in the present paper.

\section{BOUNDARY CONDITIONS OF THE STIFFENED FLANGE}

The following assumptions are made in the computational model: 1) the compressed flange of the thin-walled member behaves as an cantilever plate, elastically restrained on one side, the other edge of which is flexibly supported against deflection by the stiffener, 2) the origin of the local coordinate system of the plate $\left(x_{s}, y_{s}, z_{s}\right)$ coincides with intersection of the maximally loaded transverse edge with the elastically restrained longitudinal edge (see Fig.1), 3) transverse plate edges and the stiffener ends on the segment transverse edges are simply supported, 4) deflections of the plate free edge $\left(y_{s}=b_{s}\right)$ are the same as those of stiffener, 5) stress of the possible local buckling of the stiffener is much greater than the stress of distortional or local buckling of the flange. In the case important from the technical standpoint, the compressed flange contains a stiffener of the same thickness as the plate $\left(t_{L}=t_{s}\right)$. The effect of the flange elastic restraint against rotation at $y_{s}=b_{s}$, i.e. the effect of the stiffener torsional stiffness on the critical stress of the distortional buckling, is therefore negligible [1] and can be disregarded. The present study demonstrates that in such a situation, there is an advantageous effect of two-sided (non-symmetrical) restraint against rotation on the local buckling critical stress. Furthermore, the advantageous effect of the stiffener torsional stiffness on both local and distortional buckling critical stress is observed when $t_{L}>t_{s}$. In the present study, similar to [1], it is assumed that the edge stiffener cross-section has the shape of a narrow rectangle and the stiffener is symmetrical with respect to the middle plane of the plate. The stiffener thickness $t_{L}$ is equal to, or greater than that of the plate $t_{s}$ (see Fig.1.) The degree of the elastic restraint against rotation of the longitudinal supported edge $\left(y_{s}=0\right)$ is described by means of: 1) coefficient $\varepsilon$, in accordance with [1], varying from 0 for the simple support to $\infty$ for a built-in edge, 2) index of fixity $\kappa$, which according to [11,12] changed from 0 (for the simple support) to 1 (for a built-in edge ), as follows:

$$
\begin{gathered}
\varepsilon=C_{\theta} b_{s} / D_{s} \\
\kappa=1 /\left(1+2 D_{s} / b_{s} C_{\theta}\right)
\end{gathered}
$$


where: $C_{\theta}$ - rotational spring stiffness of the supported edge, which is equal to the bending moment that occurs in the rotation by the unit angle, $b_{s}$ - plate (wall $s$ ) width, $D_{\mathrm{s}}$ - plate flexural rigidity.

The following dependences hold between the coefficient $\varepsilon$ and the index $\kappa$ [13]:

$$
\begin{gathered}
\kappa=\varepsilon /(2+\varepsilon) \\
\varepsilon=2 \kappa /(1-\kappa)
\end{gathered}
$$

The approximate estimation of the rotational spring stiffness $C_{\theta}$ of the edge of the compressed flange, elastically restrained in the web of the thin-walled bar, can be expressed as follows [8]:

$$
C_{\theta}=\frac{\eta D_{w}}{h_{w}}\left(1-\frac{\sigma_{c r}^{D}}{\sigma_{c r, w}}\right)
$$

where: $\eta=2$ for the section subjected to compression, $\eta=4$ for the section subjected to bending (in the web plane), $D_{w}$ - plate flexural rigidity of the web, $h_{w}$ - web height between flange axes, $\sigma_{c r}{ }^{D}-$ distortional buckling stress, $\sigma_{c r, w}-$ critical stress of the local web buckling for the critical length $\left(l_{c r}\right)$ of the half-wavelength of the flange distortional buckling. It is assumed that deformations are continuous and the bending moments on the edge of flange-to-web connection are equal. It should be noted that the expression in parentheses in Eq. (2.5) accounts, in an approximate way, for the disadvantageous impact of compressive stress in the web [8]. The critical stress in the stiffening wall $\left(\sigma_{c r, w}\right)$, see Eq. (2.5), corresponds to the length of the distortional buckling of the flange. The critical stress can be estimated, in accordance with [14, 5, 6, 8], using the following formulas:

a) for the compressed web:

$$
\sigma_{c r, w}=\frac{\pi^{2} D_{w}}{t_{w} h_{w}^{2}}\left(\frac{h_{w}}{l_{c r}}+\frac{l_{c r}}{h_{w}}\right)^{2}
$$

b) for the web bent in its plane:

$$
\sigma_{c r, w}=\frac{E t_{w}^{2}}{l_{c r}^{2} h_{w}^{4}}\left(11.32 l_{c r}^{4}+1.97 h_{w}^{4}+12.06 l_{c r}^{2} h_{w}^{2}\right)
$$

On the basis of computations performed in the present study, it can be stated that for symmetrical restraint (see Fig.1), the critical length of distortional buckling (for the range most frequently found 
in practice, i.e. for the fixity index $0 \leq \kappa \leq 0.7$ ) can be estimated, according to $[5,6]$, from the formula:

$$
l_{c r}=4.8\left(\frac{I_{L} b_{s}^{2} h_{w}}{n t_{s}^{3}}\right)^{0.25}
$$

where: $n=1$ for the section subjected to compression, $n=2$ for the section subjected to bending, and $I_{L}=t_{L} b_{L}{ }^{3} / 12-$ moment of inertia of the stiffener.

Computations become iterative, because to calculate the rotational spring stiffness $C_{\theta}$, it is necessary to know the critical stress $\sigma_{c r}{ }^{D}$, which, according to Eq. (2.2), depends on $\kappa$, and thus on $C_{\theta}$. The process, however, is converging fast, and most often it is sufficient to perform only two or three iterations.

\section{DEFLECTION FUNCTIONS}

The section flange is composed of the cantilever plate, elastically restrained on one side [13], and the "beam stiffener", which is susceptible to deflection [4]. To approximate the complex buckling mode, the following formulas are used:

a) for the plate:

$$
w_{s}\left(x_{s}, y_{s}\right)=t_{s} \sum_{i=1}^{i_{o}}\left[f_{i 2}\left((1-\kappa) \frac{y_{s}}{b_{s}}+\kappa\left(\frac{y_{s}}{b_{s}}\right)^{2}\right)+\sum_{p=3}^{p_{o}} f_{i p}\left(\frac{y_{s}}{b_{s}}\right)^{p}\right] \sin \left(\frac{i \pi x_{s}}{l_{s}}\right)
$$

b) for the "beam stiffener":

$$
w_{L}\left(x_{s}\right)=w_{s}\left(x_{s}, y_{s}=b_{s}\right)=t_{s} \sum_{i=1}^{i_{o}}\left(f_{i 2}+\sum_{p=3}^{p_{o}} f_{i p}\right) \sin \left(\frac{i \pi x_{s}}{l_{s}}\right)
$$

where: $t_{s}, b_{s}$ - plate (wall $s$ ) thickness, width, $l_{s}$ - length of the plate and the stiffener, $f_{i 2}, f_{i p}-$ free, dimensionless parameters of the deflection function.

Deflection functions that are assumed make it possible to identify: 1) the distortional buckling mode of the plate - stiffener system, 2) local buckling mode of the internal plate supported by the edge stiffener being "insusceptible" to deflection, and 3) interactive mode of local and distortional buckling. 


\section{STRESS STATE IN THE SECTION FLANGE}

In the stability analysis of the compressed flange, being a component of the thin-walled member with an open section, in which the hypothesis on flat sections walls is accepted, normal stress distribution (see Fig.1) can be presented as follows:

$$
\sigma_{x}=\sigma_{0} \beta_{i}\left(x_{s}\right)
$$

where: $\sigma_{0}$ - maximum compressive stress (positive) on the edge containing the origin of the local system of coordinates $\left(y_{s}=0\right.$, see Fig. 1$), \beta_{i}\left(x_{s}\right)$ - function of the stress distribution along the plate length. In the present study, the following cases of longitudinal stress distribution are taken into consideration: 1) constant distribution $\left.\left(m_{i}=0\right), 2\right)$ linear distribution, and 3) non-linear distribution in accordance with the $2^{\text {nd }}$ degree parabola. In cases 2 and 3, the function $\beta_{i}\left(x_{s}\right)$ in Eq. (4.1) can be respectively presented as:

$$
\beta_{1}\left(x_{s}\right)=1-m_{1} x_{s} / l_{s}
$$

$$
\beta_{2}\left(x_{s}\right)=1-m_{2} x_{s}^{2} / l_{s}^{2}
$$

where: $m_{i}$ - coefficient that characterises longitudinal stress variation in accordance with formula:

$$
m_{i}=1-\sigma_{1} / \sigma_{0}
$$

Variation of normal stress along the cantilever plate length, according to Eq. (4.1), can be obtained by generating shear stresses or longitudinal body forces (see Fig.1) with the distribution dependent on the loading conditions of thin-walled bar. The way of replacing shear stresses by appropriate distribution of body forces was described in study [15] for internal plates, and in [3] for cantilever plates. When the thin-walled member is bent, e.g. with respect to the major axis of stiffness of a typical $\mathrm{C}$ or $\mathrm{Z}$ section, at the height of the stiffener, non-uniform (linear) stress distribution occurs. To simplify the calculations of the critical load, it is assumed from the distortional buckling condition that mean stress acts in the stiffener: $\sigma_{0}=\left(\sigma_{a}+\sigma_{b}\right) / 2$ (see Fig.1). In this case, stress distribution in the stiffener can be written in accordance with Eq. (4.1). 


\section{ELASTIC STRAIN ENERGY AND THE WORK DONE BY EXTERNAL FORCES}

In study [3], it was shown how to determine the total potential energy $\left(U_{s}=V_{s, 1}-L_{s}\right)$ of the compressed cantilever plate (without stiffened edge) when the deflection function is written as a polynomial-sine series, e.g. in the form of Eq. (3.1). In this case, the elastic strain energy $\left(V_{s, 1}\right)$ can be determined in the way proposed in study [16], and the function of external forces $\left(L_{s}\right)$ can be determined from the sequence of formulas derived in [3].

The energy of the elastic restraint against rotation $\left(V_{s, 2}\right)$ of the supported plate edge (at $\left.y_{s}=0\right)$ is determined from formula:

$$
V_{s, 2}=\frac{C_{\theta}}{2} \int_{0}^{l_{s}}\left[\left(\frac{\partial w_{s}}{\partial y_{s}}\right)_{y_{s}=0}^{2}\right] d x_{s}
$$

The energy of the stiffener in bending is calculated from formula:

$$
V_{L, 1}=\frac{E I_{L}}{2} \int_{0}^{l_{s}}\left(\frac{d^{2} w_{L}}{d x_{s}^{2}}\right)^{2} d x_{s}
$$

When it is necessary to account for the advantageous effect of torsional stiffness of the stiffener, the torsional strain energy can be determined, according to [1], from the following formula:

$$
V_{L, 2}=\frac{C_{L}}{2} \int_{0}^{l_{s}}\left(\frac{\partial \theta}{\partial x_{s}}\right)^{2} d x_{s}=\frac{C_{L}}{2} \int_{0}^{l_{s}}\left[\left(\frac{\partial^{2} w_{s}}{\partial x_{s} \partial y_{s}}\right)_{y_{s}=b_{s}}\right]^{2} d x_{s}
$$

where: $\theta$ - stiffener rotation angle, $C_{L}$ - torsional rigidity, which, for stiffener having narrow rectangular cross-section [1], can be estimated as follows:

$$
C_{L}=\frac{1}{3} b_{L} t_{L}^{3} \frac{E}{2(1+v)}
$$

where: $E$ - modulus of elasticity, $v$ - Poisson's ratio.

The work done by external forces in the stiffener at flexural buckling and longitudinal stress variation is calculated from the formula: 


$$
L_{L, 1}=-\frac{A_{L}}{2} \int_{0}^{l_{s}} \sigma_{0} \beta_{\mathrm{i}}\left(x_{\mathrm{s}}\right)\left(\frac{d w_{L}}{d x_{s}}\right)^{2} d x_{s}
$$

where: $A_{L}=t_{L} b_{L}-$ stiffener cross-section area.

The work done by external forces in the stiffener at torsional buckling can be determined from formula:

$$
L_{L, 2}=-\frac{J_{0}}{2} \int_{0}^{l_{s}} \sigma_{o} \beta_{\mathrm{i}}\left(x_{\mathrm{s}}\right)\left(\frac{d \theta}{d x_{s}}\right)^{2} d x_{s}=-\frac{J_{0}}{2} \int_{0}^{l_{s}} \sigma_{o} \beta_{\mathrm{i}}\left(x_{\mathrm{s}}\right)\left[\left(\frac{\partial^{2} w_{s}}{\partial x_{s} \partial y_{s}}\right)_{y_{s}=b_{s}}\right]^{2} d x_{s}
$$

where: $J_{0}$ - polar moment of inertia of the stiffener (for rectangular section: $J_{0}=t_{L} b_{L}\left(b_{L}{ }^{2}+t_{L}{ }^{2}\right) / 12$ ).

\section{Critical Stress}

The critical stress $\left(\sigma_{c r}\right)$ of local or distortional buckling of axially compressed, elastically restrained against rotation member flange with a stiffener is referred to the most compressed plate edge. The critical stress is expressed with the following formula:

$$
\sigma_{c r}=k \sigma_{E}
$$

where: $\sigma_{E}$ - Euler's stress for the plate in accordance with formula:

$$
\sigma_{E}=\frac{\pi^{2} E}{12\left(1-v^{2}\right)}\left(\frac{t_{s}}{b_{s}}\right)^{2}
$$

Plate buckling coefficients $(k)$ is determined using the energy method. The total potential energy of the plate - stiffener system was determined from the formula:

$$
U_{s}=V_{s, 1}+V_{s, 2}+V_{L, 1}+V_{L, 2}-L_{s}-L_{L, 1}-L_{L, 2}
$$

where: $V_{s, 1}$ - elastic strain energy of the plate in bending, according to [16], $V_{s, 2}$ - energy of the elastic restraint, from Eq. (5.1), $V_{L, 1}$ - elastic strain energy of the stiffener in bending, from Eq (5.2), $V_{L, 2}$ - elastic strain energy of the stiffener in torsion, from Eq. (5.3), $L_{s}$ - work done by external forces in the plate, in accordance with [3], $L_{L, 1}, L_{L, 2}$ - work done by external forces in the stiffener, 
from Eq. (5.5) and Eq. (5.6).

The critical stress of the reliable buckling mode is calculated from the system of equations:

$$
\partial U_{s} / \partial f_{i p}=0
$$

reducing the stability problem to eigenproblem of determining eigenvalues and eigenvectors.

In the present study, computational program Ncr-plate-cantilever-sym-stiffener.nb developed with Mathematica ${ }^{\circledR}$ software package is employed to determine coefficients $k$. The program makes it possible to calculate the critical stress and coefficients $k$ and to present the calculation results in a graphic form (e.g. graphs, buckling modes). The plate deflection function is adopted according to Eq. (3.1), with $p_{0}=4$, and with initial values of the fixity index. According to Eq. (2.2), the fixity index varies from $\kappa=0$, for simply supported edge, to $\kappa=1$, for built-in edge. The stiffener deflection function is adopted according to Eq. (3.2). Parameter $i_{0}$, which in Eq. (3.1) and Eq. (3.2) specifies the number of half-wavelengths of the sine function in the direction of axis $x_{s}$ is selected with regard to the plate dimension ratio $\left(\gamma_{s}=l_{s} / b_{s}\right)$ and the reliable buckling mode. On the basis of the analysis of convergence of the results, analogous to the one presented in study [3], for the calculations of stiffened plates in the range $\gamma_{s} \leq 20, b_{L} / b_{s} \geq 0.1$ and $0 \leq m \leq 1$, parameter $i_{0}$ can be taken from the interval $10 \leq i_{0} \leq 20$. The graphs of coefficients $k$ presented in this study are plotted for $E=205 \mathrm{GPa}$ and $v=0.3$. Table 1 shows how curve numbers in the graphs (Fig.2 and Fig.3) are assigned to coefficient $\varepsilon$ and index $\kappa$.

Table 1. Assignment of curve numbers from Figs 2 and 3 to the coefficient $\varepsilon$ and index $\kappa$

\begin{tabular}{|c|c|c|c|c|c|c|c|c|}
\hline $\mathrm{Nr}$ & 1 & 2 & 3 & 4 & 5 & 6 & 7 & 8 \\
\hline$\varepsilon$ & 0 & 0.2 & 0.6 & 1.5 & 3 & 8 & 30 & $10^{5}$ \\
\hline$\kappa$ & 0 & 0.091 & 0.231 & 0.429 & 0.6 & 0.8 & 0.938 & 1 \\
\hline
\end{tabular}

Fig.2 shows graphs of coefficient $k$ for the elastically restrained (curve number in accordance with Table 1) cantilever plate $\left(b_{s} / t_{s}=35\right)$ with edge stiffener $\left(b_{L} / b_{s}=0.2, t_{L} / t_{s}=1\right)$, at linear stress distribution $\left(m_{1}=1\right)$. The upper dotted line is used to separate the range $\left(\gamma_{s}<2.5 \div 3\right)$ of occurrence of the interactive, local - distortional $(L D)$ buckling mode from the basic range $\left(2.5 \div 3<\gamma_{s}\right)$, in which distortional buckling is found $(D)$. The lower broken line marks the graph of coefficient $k$ that is determined when the torsional stiffness of the stiffener is disregarded for $\kappa=0$. Comparison of the graphs (curve 1 - solid line versus broken line) indicates that for $t_{L} / t_{s}=1$, the effect of the stiffness of the stiffener torsion on distortional buckling is minimal and, from the technical standpoint, can be 
disregarded [1,4]. With the growth of the fixity index $\kappa$, coefficients $k$ increase. However, when parameter $\gamma_{s}$ grows, coefficients $k$ decrease.

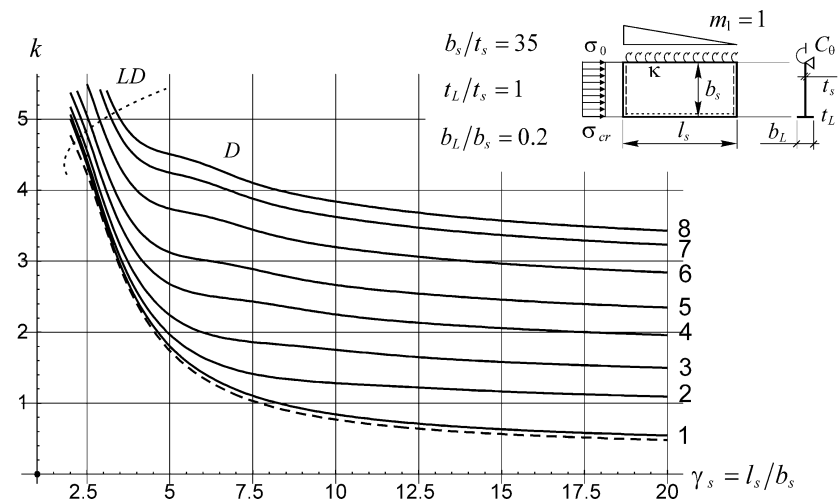

Figure 2. Graphs of coefficient $k$ for different values of index $\kappa$ (Table 1) for $m_{1}=1$

Fig. 3 shows graphs of coefficient $k$ for the elastically restrained (curve number in accordance with Table 1) cantilever plate $\left(b_{s} / t_{s}=60\right)$ with edge stiffener $\left(b_{L} / b_{s}=0.25, t_{L} / t_{s}=2\right)$, at non-linear stress distribution $\left(m_{2}=1\right)$. The dotted line separates the ranges of occurrence of local buckling modes $(L)$ of the "internal plate" from those of distortional buckling $(D)$ of the cantilever plate-stiffener system. In this case, practically no occurrence of the interactive mode $(L D)$ is found. Graphs of coefficients $k$ at the buckling mode change (curve intersections with the dotted line) are characterised by a typical "fault". As in the previous figure, the bottom broken line marks the coefficient $k$ that is determined when the torsional stiffness of the stiffener is disregarded for $k=0$. Comparison of the graphs (curve 1 - solid line versus broken line) indicates that for $t_{L} / t_{s}=2$, the effect of the stiffness of the stiffener torsion is significant for both local buckling (av. increase of approx. 28\%) and distortional buckling. The range of occurrence of the reliable buckling modes is also changed, because taking into account the torsional stiffness enlarges the range $\left(\gamma_{s}\right)$ of distortional buckling occurrence (compare the coordinate of the curve 1 "fault" with the broken line). Similar results are obtained for other figures (Figs. $2 \div 6$ ). Additionally, the comparison of the graphs indicates that an increase in index $\kappa$ is accompanied by an increase in coefficients $k$ of the critical stress, for both local and distortional buckling. Increase in coefficients $k$, is much higher for distortional buckling. Beyond the "fault", however, coefficients $k$ decrease rapidly with the plate length, especially for the low values of $\kappa$ (see curves no. 1,2,3,4 in Fig.3). 


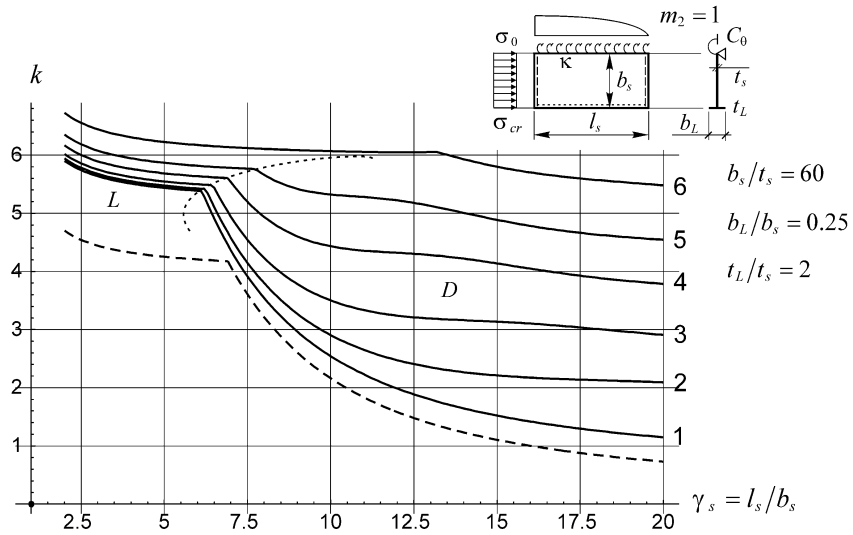

Figure 3. Graphs of coefficient $k$ for different values of index $\kappa$ (Table 1) for $m_{2}=1$

Fig.4 shows graphs of coefficient $k$ for the elastically restrained $(\varepsilon=2, \kappa=0.5)$ cantilever plate $\left(b_{s} / t_{s}\right.$ $=50)$ with the edge stiffener $\left(b_{L} / b_{s}=0.25 ; t_{L} / t_{s}=1.5\right)$ at linear stress distribution along the plate length, according to Eq. (4.1) and Eq. (4.2) for $m_{1}=0 ; 0.25 ; 0.5 ; 0.75$ and 1 . As in the previous figures, the bottom broken line marks the graph of coefficient $k$ that is determined when the torsional stiffness of the stiffener is disregarded for $m_{1}=0$. In this case, the comparison of the graphs indicates that for $t_{L} / t_{s}=1.5$, the advantageous effect of the stiffness of the stiffener torsion is also noticeable, especially for local buckling. Dotted lines are used to separate the ranges of occurrence of local buckling $(L)$, local and distortional buckling interaction $(L D)$, and distortional buckling $(D)$. With an increase in the value of parameter $m_{1}$, the range of occurrence of the interactive buckling mode $(L D)$ is enlarged.

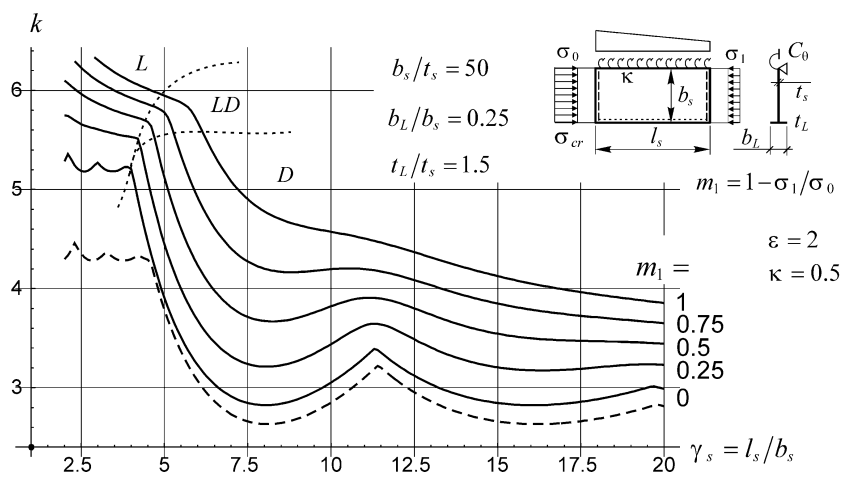

Figure 4. Graphs of coefficient $k$ for linear stress distribution and different values of $m_{1}$ 
The curves of coefficient $k$ for $m_{1}=0$ (Fig. 4) are garland in character, both in the range of local buckling occurrence and in the distortional buckling range, which makes it possible to evaluate the number of half-wavelengths of the reliable buckling mode. For longitudinal stress variation $\left(m_{1}>0\right)$, with an increase in parameter $m_{i}$, coefficients $k$ increase and their graphs loose their garland character. In this case, buckling half-wavelengths are formed along the plate length. Those are varied in length and have decreasing amplitudes [13].

Exemplary buckling modes for the elastically restrained cantilever plate with the stiffener, determined using the Ncr-plate-cantilever-sym-stiffener.nb software, are presented in Fig.5. (geometric details, support and loading diagrams are included in this figure). The example corresponds to coefficients $k$ (curve $m_{1}=1$ in Fig.4.) of the critical stress that is characterised by different buckling modes. Fig.5a shows local buckling mode (on the range boundary $L, \gamma_{s}=4.8$ ). In Fig.5b, a fully developed interactive mode (approximately in the middle of the range $L D, \gamma_{s}=5.5$ ) can be seen, whereas in Fig. $5 \mathrm{c}$, the distortional buckling mode (on the range boundary $D, \gamma_{s}=6.2$ ) is shown. Note that the edge stiffener is removed from Fig.5abc to make the buckling mode more visible.

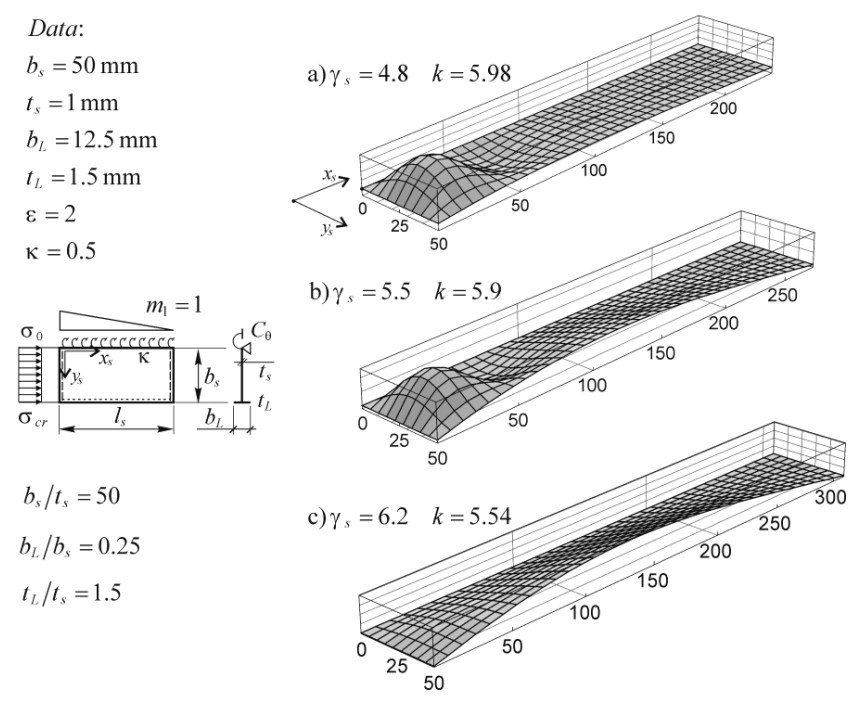

Figure 5. Buckling modes in an exemplary cantilever plate with an edge stiffener

In this case, the comparison of buckling modes shows that: 1) the local mode (L) "consists" of two basic buckling "half-wavelengths" that have radically different amplitudes (the "critical half- 
wavelength" having the maximum amplitude [13] is found on the edge side that is more loaded $\left.x_{s}=0\right), 2$ ) the interactive mode (LD) is characterised by both "plate" and "beam" deflections, and 3) the distortional mode (D) consists of one, gently asymmetrical half-wavelength of the buckling of the cantilever plate with the stiffener (the maximum amplitude is found for the coordinate $x_{s}=120<$ $310 / 2=155 \mathrm{~mm}$ ).

Fig.6 shows graphs of coefficient $k$ for the elastically restrained $(\varepsilon=1.5 ; \kappa=0.429)$ cantilever plate $\left(b_{s} / t_{s}=40\right)$ with the edge stiffener $\left(t_{L} / t_{s}=1\right)$ for different ratios $b_{L} / b_{s}=0.1 \div 0.35$ at linear stress distribution $\left(m_{1}=1\right)$. Dotted lines are used to separate the ranges of occurrence of local buckling $(L)$, local and distortional buckling interaction $(L D)$, and distortional buckling $(D)$. In this case, the comparison of the graphs indicates that an increase in the ratio $b_{L} / b_{s}$ is accompanied by an increase in the coefficients of the critical stress of the reliable buckling mode. Additionally, it can be observed that in the range of distortional buckling (e.g. $\gamma_{s}>10$ ), a constant increment of the ratio $b_{L} / b_{s}$ (from 0.1 to 0.35 with an interval of 0.05 ) is accompanied by the constant increment of coefficient $k$.

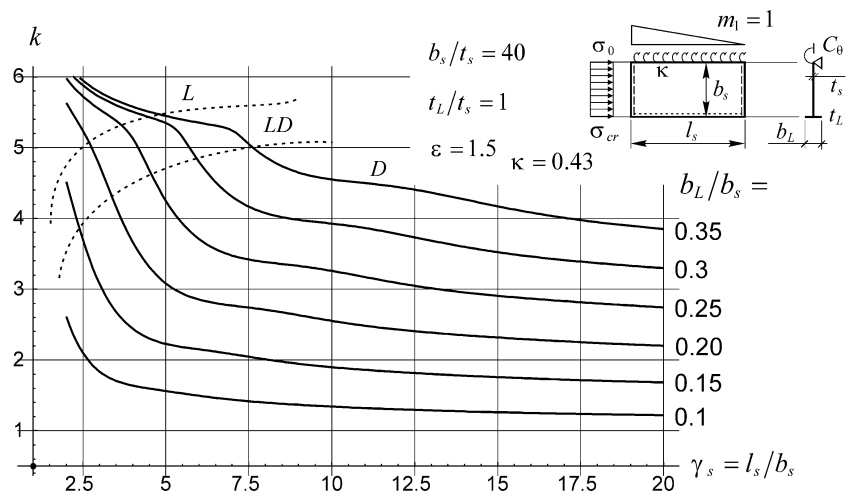

Figure 6. Graphs of coefficient $k$ for different $b_{L} / b_{s}$ ratios

Fig.7 shows graphs of coefficient $k$ for the elastically restrained $(\varepsilon=3, \kappa=0.6)$ cantilever plate $\left(b_{s} / t_{s}\right.$ $=50$ ) with the edge stiffener $\left(b_{L} / b_{s}=0.3\right)$ for different ratios $t_{L} / t_{s}=1 \div 2.5$ at non-linear stress distribution $\left(m_{2}=1\right)$. Dotted lines mark the boundaries of ranges of the reliable buckling mode. In this case, similar to Fig.3, practically no occurrence of the interactive mode $(L D)$ is found. With an increase in the stiffener thickness, the value of buckling coefficient grows, especially for the local buckling of the internal plate. For instance, for $\gamma_{s}=7.5$ (local buckling), the increment of coefficient $k$ value between $t_{L} / t_{s}=1$ and 2.5 amounts to approx. $16 \%$, and for $\gamma_{s}=15$ (distortional buckling), the 
increment is approx. 9\%. As before, the lower broken line marks the coefficient $k$ determined when the torsional stiffness of the stiffener is disregarded for $t_{L} / t_{s}=1$. In this case, the differences are observed primarily in the local buckling range $(L)$, and are of the order of $10 \%$.

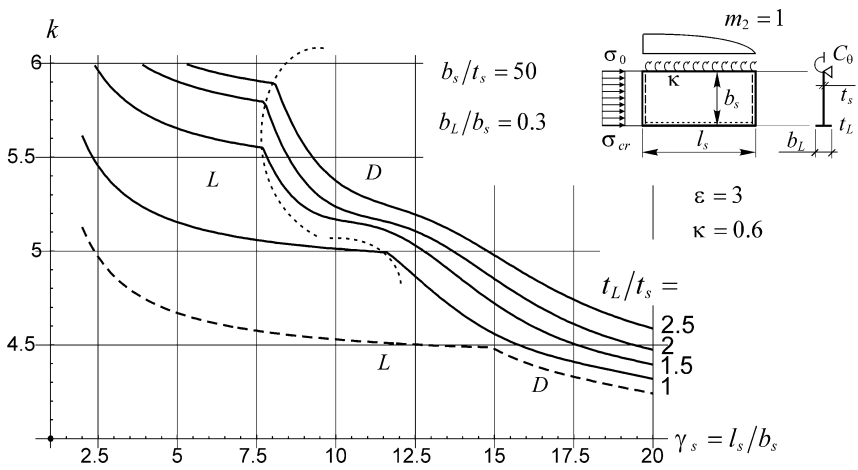

Figure 7. Graphs of coefficient $k$ for different $t_{L} / t_{s}$ ratios

Fig. 8 shows graphs of coefficient $k$ for the elastically restrained $(\varepsilon=1, \kappa=0.333)$ cantilever plate with the edge stiffener $\left(b_{L} / b_{s}=0.15, t_{L} / t_{s}=1\right)$ for different slenderness of the plate $b_{s} / t_{s}=20 \div 60$ at linear stress distribution $\left(m_{1}=0.5\right)$. In the whole range $\gamma_{s}$, shown in Fig.8 (for individual slenderness values), the distortional buckling mode occurs $(D)$. The comparison of results shows that an increase in the plate slenderness is accompanied by an increase in the advantageous effect produced by the plate "support" on the stiffener, and also by an increase in the values of buckling coefficients. It is obvious that the distortional buckling critical stress decreases due to a rapid drop of $\sigma_{E}$, related to the growing plate slenderness (see Eq. (6.2)).

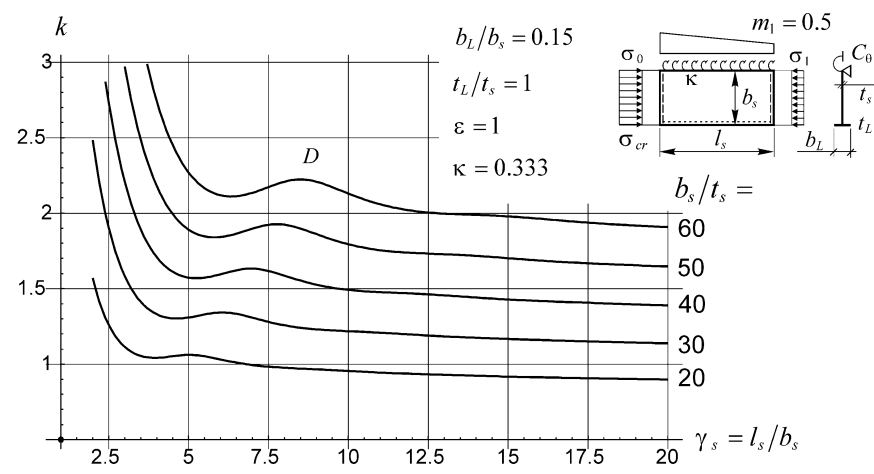

Figure 8. Graphs of coefficient $k$ for different slenderness of the plate $b_{s} / t_{s}$ 


\section{CONCLuSIONS}

The computational model employed in the study, in which the degree of the wall elastic restraint and stress variation along the length of the thin-walled bar segment are taken into account, gives more accurate determination of the critical stress of the reliable buckling mode. That especially refers to cantilever plates with edge stiffener. For such plates, the reserves of the distortional critical resistance (i.e. critical resistance resulting from the condition of distortional buckling), which originate from the elastic restraint against rotation of the supported edge, are greater than for internal walls, elastically restrained on two sides, with intermediate stiffener [1, 9]. The computational model is improved due to taking into account the torsional stiffness of the stiffener and the work done by the axial force in the stiffener. That makes it possible to represent, in a more accurate way, the actual stability behaviour of the thin-walled member section walls. The use of adopted deflection functions for the cantilever plate and the stiffener in the study allows the analysis of the distortional buckling of the plate - stiffener system, of the local buckling of the "internal" plate supported by "inflexible" edge stiffening, and also of the interactive mode at longitudinal stress variation. Additionally, deflection functions also make it possible to account for the elastic restraint of the member section wall against rotation on both the edge supported by the web and on the flexible support against deflection (on the "free edge"). An increase in the value of index $\kappa$, according to Eq. (2.2), and in parameter $m_{i}$ of the longitudinal stress distribution, according to Eq. (4.4), results in an increase in coefficients of the critical stress of local and distortional buckling in respective ranges $\gamma_{s}$. The same trend is found for an increase in the ratios: 1) $b_{L} / b_{s}$ and 2) $t_{L} / t_{s}$, and for distortional buckling, for an increase in ratio: 3) $b_{s} / t_{s}$ (for the constant value of $b_{L} / b_{s}$ ). In this third case, coefficient $k$ grows, but the critical stress obviously decreases due to the reduction in $\sigma_{E}$ for the growing slenderness of the plate. Lower values of the coefficient $k$, at the same values of parameters $\kappa, m$ and $\gamma_{s}$, are obtained for non-linear stress distribution along the plate length. None of the graphs presented in this study (Figs. 2 - 4 and 6 - 8), except for curves $m_{1}=0$ in Fig.4, are typical garland curves, as it is the case for $m=0[1,14,4,9]$. Therefore, the graphs do not unequivocally indicate the number of half-wavelengths of the reliable mode of local or distortional buckling which are generated over the length of the thin-walled bar segment. That results from longitudinal stress variation. Complex modes of buckling that occur in this case can be determined with the Ncr-plate-cantilever-sym-stiffener.nb software. The comparison of coefficients $k$ graphs presented in this study indicates that, for short segments, the reliable mode of stability loss of the stiffened flange can be local buckling of the "internal plate". For longer segments, however, the 
reliable mode of stability loss is the distortional buckling of the plate - stiffener system. In many cases, on the boundary of ranges ( $L$ and $D$ ), interactive buckling mode $(L D)$ was also revealed.

\section{REFERENCES}

1 Bulson P.S. The Stability of Flat Plates. Chatto and Windus. London 1970.

2 Dinis PB., Camotim D. Local/distortional mode interaction in cold-formed steel lipped channel beams. Thin-Walled Structures 2010; 48 (10-11): 771-785.

3 Szychowski A. The stability of eccentrically compressed thin plates with a longitudinal free edge and with stress variation in the longitudinal direction. Thin-Walled Structures 2008; 46 (5): 494-505.

4 Szychowski A. Buckling of elastically restrained cantilever wall with free edge stiffening (in Polish). Budownictwo i Architektura Vol.13(3) 2014: 291-298.

5 Lau S.C.W., Hancock G.J. Distortional buckling formulas for channel columns. J. Struct. Engng ASCE, 113(5); 1987:1063-1078.

6 Hancock G.J. Design for Distortional Buckling of Flexural Members. Thin-Walled Structures 1997; 27 (1): 3-12.

7 Schafer B., Peköz T. Laterally braced cold-formed steel flexural members with edge stiffened flanges. Journal of Structural Engineering 1999, Vol. 125, No 2, 118 - 126.

8 Li L-y., Chen J-k. An analytical model for analyzing distortional buckling of cold-formed steel sections. ThinWalled Structures 46 (2008): 1430-1436.

9 PN-EN 1993-1-3. Eurocode 3. Design of steel structures. Part 1-3: General rules - Supplementary rules for coldformed members and sheeting.

10 Szychowski A. Stability of unsymmetrical elastically restrained internal plates with longitudinal stress variation (in Polish). Zeszyty Naukowe Politechniki Rzeszowskiej No. 283, Series: Budownictwo i Inżynieria Środowiska, Vol. 59, No. 3/2012/II, 429-436.

11 Wiśniewski L. Local stability loss of the metal bar web with the participation of flanges (in Polish). Archiwum Inżynierii Lądowej 11, 2/1965, 253-276.

12 Rykaluk K. Residual welding stresses in chosen ultimate bearing capacity (in Polish). Prace Naukowe Instytutu Budownictwa Politechniki Wrocławskiej, 29, series: Monografie 11, Wrocław 1981.

13 Szychowski A. Stability of cantilever walls of steel thin-walled bars with open cross-section. Thin-Walled Structures 94 (2015): 348-358.

14 Timoshenko S.P., Gere J.M. Theory of Elastic Stability. Part II. McGraw-Hill, New York, N.Y. 1961.

15 Kowal Z. The stability of compressed flange of plate girder with a box section (in Polish). Zeszyty Naukowe Politechniki Wrocławskiej, Budownictwo 1965;122: 73-85.

16 Jakubowski S., The matrix analysis of stability and free vibrations of walls of thin-walled girders (in Polish). Archiwum Budowy Maszyn (1986), Vol. XXXIII, Z.4, 357-375. 


\section{LIST OF FIGURES AND TABLES:}

Fig. 1. Compressed flange isolated from thin-walled bar segment

Rys. 1. Wydzielona z segmentu pręta cienkościennego półka ściskana

Fig. 2. Graphs of coefficient $k$ for different values of index $\kappa$ (Table 1) for $m_{1}=1$

Rys. 2. Wykresy współczynnika $k$ dla różnych wartości wskaźnika $\kappa$ (Tab. 1) przy $m_{1}=1$

Fig. 3. Graphs of coefficient $k$ for different values of index $\kappa$ (Table 1) for $m_{2}=1$

Rys. 3. Wykresy współczynnika $k$ dla różnych wartości wskaźnika $\kappa$ (Tab. 1) przy $m_{2}=1$

Fig. 4. Graphs of coefficient $k$ for linear stress distribution and different values of $m_{1}$

Rys. 4. Wykresy współczynnika $k$ przy liniowym rozkładzie naprężeń i różnych wartościach $m_{1}$

Fig. 5. Buckling modes in an exemplary cantilever plate with an edge stiffener

Rys. 5. Postacie wyboczenia przykładowej płyty wspornikowej z usztywnieniem krawędzi

Fig. 6. Graphs of coefficient $k$ for different $b_{L} / b_{s}$ ratios

Rys. 6. Wykresy współczynnika $k$ dla różnych relacji $b_{L} / b_{s}$

Fig. 7. Graphs of coefficient $k$ for different $t_{L} / t_{s}$ ratios

Rys. 7. Wykresy współczynnika $k$ dla różnych relacji $t_{L} / t_{s}$

Fig. 8. Graphs of coefficient $k$ for different slenderness of the plate $b_{s} / t_{s}$

Rys. 8. Wykresy współczynnika $k$ dla różnych smukłości płyty $b_{s} / t_{s}$

Tab. 1. Assignment of curve numbers from Figs 2 and 3 to the coefficient $\varepsilon$ and index $\kappa$

Tab. 1. Przyporządkowanie numeru krzywej na rys.2 i 3 do współczynnika $\varepsilon$ oraz wskaźnika $\kappa$ 


\section{WYBOCZENIE PÓŁKI USZTYWNIONEJ ELEMENTU CIENKOŚCIENNEGO PRZY WZDLUŻNEJ ZMIENNOŚCI NAPREŻEŃ}

Słowa kluczowe: kształtowniki cienkościenne, wyboczenie lokalne, wyboczenie dystorsyjne, sprężyste zamocowanie krawędzi, wzdłużna zmienność naprężeń

\section{STRESZCZENIE:}

Współcześnie stosowane elementy cienkościenne o przekroju otwartym charakteryzują się dużymi smukłościami ścianek. W związku z tym są wrażliwe na zjawiska lokalne związane z ich wyboczeniem. $\mathrm{Z}$ tego punktu widzenia, krawędź swobodną ściskanej ścianki wspornikowej wzmacnia się często usztywnieniem krawędziowym, powodując wzrost naprężeń krytycznych i zmianę miarodajnej postaci wyboczenia. Usztywniona ścianka wspornikowa jest w większości przypadków sprężyście zamocowana przeciw obrotowi w ściance przęsłowej (np. w środniku kształtownika cienkościennego) i często występuje w niej wzdłużna zmienność naprężeń.

W pracy utratę stateczności półki elementu cienkościennego o przekroju otwartym sprowadzono do analizy wyboczenia sprężyście zamocowanej przeciw obrotowi płyty wspornikowej z podatnym na ugięcie usztywnieniem drugiej krawędzi. Jednocześnie uwzględniono wzdłużną zmienność naprężeń.

W modelu obliczeniowym przyjęto następujące założenia: 1) ściskana półka kształtownika cienkościennego zachowuje się jak jednostronnie sprężyście zamocowana płyta wspornikowa z drugim brzegiem podatnie podpartym na ugięcie „belką” usztywnienia, 2) początek lokalnego układu współrzędnych płyty $\left(x_{s}, y_{s}, z_{s}\right)$ umieszczono na przecięciu (styku) maksymalnie obciążonej krawędzi poprzecznej ze sprężyście zamocowaną krawędzią podłużną (por.rys.1), 3) poprzeczne krawędzie płyty oraz końce „belki” usztywnienia na poprzecznych krawędziach segmentu są swobodnie podparte, 4) występuje zgodność ugięć swobodnej krawędzi płyty $\left(y_{s}=b_{s}\right)$ z ugięciami usztywnienia, 5) naprężenia ewentualnego wyboczenia lokalnego usztywnienia są znacznie większe od naprężeń wyboczenia dystorsyjnego lub lokalnego półki.

Ponadto w pracy przyjęto, że usztywnienie krawędzi swobodnej ma przekrój wąskiego prostokąta i jest symetryczne względem płaszczyzny środkowej płyty, a jego grubość jest równa lub większa od grubości płyty.

Stopień sprężystego zamocowania przeciw obrotowi uzależniono od sztywności obrotowej podłużnej krawędzi podpartej $\left(y_{s}=0\right)$ i opisano za pomocą: 1) współczynnika $\varepsilon$ zmieniającego się od 0 dla podparcia przegubowego do $\infty$ dla pełnego utwierdzenia, oraz 2) wskaźnika utwierdzenia $\kappa$ zmieniającego się od 0 (dla przegubu) do 1 (dla pełnego utwierdzenia).

Do aproksymacji postaci wyboczenia płyty wspornikowej i usztywnienia zastosowano funkcje zbudowane z podwójnych szeregów wielomianowo - sinusowych. Tak przyjęte funkcje ugięć umożliwiły aproksymację: 1) postaci wyboczenia dystorsyjnego układu płyta - usztywnienie, 2) postaci wyboczenia lokalnego płyty „przęsłowej” podpartej na „niepodatnym” na ugięcie usztywnieniu krawędziowym, oraz 3) postaci interakcyjnej wyboczenia lokalnego i dystorsyjnego na granicy przedziałów.

Zmienność naprężeń normalnych na długości płyty wspornikowej i usztywnienia uzyskano przez wprowadzenie wzdłużnych sił masowych (por.rys.1) o rozkładzie dobranym w zależności od sposobu obciążenia elementu cienkościennego. 
Płytowe współczynniki wyboczeniowe $(k)$ wyznaczono metodą energetyczną. W tym celu opracowano w środowisku pakietu Mathematica ${ }^{\circledR}$ program obliczeniowy „Ncr-plate-cantilever-sym-stiffener.nb”. Program oblicza naprężenia krytyczne i współczynniki $k$ oraz umożliwia graficzną prezentację wyników obliczeń i różnych postaci wyboczenia. Na rysunkach przedstawiono liczne wykresy współczynnika $k$ w zależności od 1) wskaźnika $\kappa$ sprężystego utwierdzenia, 2) parametru $m_{i}$ wzdłużnego rozkładu naprężeń wg funkcji liniowej lub paraboli 2. stopnia, 3) szerokości i grubości usztywnienia oraz, 4) smukłości płyty. Zamieszczono również przykładowe postacie wyboczenia lokalnego $(L)$, dystorsyjnego $(D)$ i interakcyjnego $(L D)$.

Zastosowany w pracy model obliczeniowy prowadzi do dokładniejszego wyznaczenia naprężeń krytycznych miarodajnej postaci wyboczenia. Ze wzrostem wskaźnika $\kappa$ oraz parametru $m_{i}$ rosną współczynniki naprężeń krytycznych wyboczenia lokalnego i dystorsyjnego w miarodajnych przedziałach $\gamma_{s}=l_{s} / b_{s}$. Mniejsze współczynniki $k$ przy tych samych wartościach parametrów $\kappa, m$ oraz $\gamma_{s}$ uzyskano dla nieliniowego rozkładu naprężeń na długości płyty. Z porównania wykresów współczynnika $k$ zamieszczonych w pracy wynika, że dla segmentów krótkich miarodajną postacią utraty stateczności półki usztywnionej może być wyboczenie lokalne „płyty przęsłowej”. Natomiast dla segmentów dłuższych miarodajną postacią utraty stateczności jest wyboczenie dystorsyjne układu: płyta - usztywnienie. W wielu przypadkach, na granicy przedziałów $(L$ i $D)$, ujawniono również interakcyjną postać wyboczenia $(L D)$. 